\title{
Concept Maps powered by computer software: a strategy for enhancing reading comprehension in English for Specific Purposes
}

\section{Mapas conceituais mediados pelo computador: uma estratégia para aumentar o nível de compreensão escrita em inglês para fins específicos}

Reinildes Dias*

Universidade Federal de Minas Gerais

Belo Horizonte - Minas Gerais / Brasil

\begin{abstract}
This paper focuses on the procedures of an action-research (STRINGER, 2007) that was conducted with undergraduates enrolled in an ESP course at Faculdade de Letras (UFMG). The impelling drive was the creation of a means to solve an educational problem, namely, the enhancement of students' reading comprehension of texts in English for academic purposes. The problemsolving process involved the use of concept maps (NOVAK; CANAS, 2008) powered by the CMap Tools software (CANAS et al., 2004) to meet the educational needs of a localized teaching situation. Data indicate that concept mapping, facilitated by computer software, can be a useful strategy to improve comprehension. Support for the investigation comes from the theories underlying the ESP approach, meaningful learning, learning as a social enterprise, and collaborative learning.

KEY WORDS: concept maps, CMap tools software, reading comprehension for specific purposes in English.

RESUMO: Este artigo enfoca os procedimentos de uma pesquisa-ação (STRINGER, 2007) implementada em uma turma de alunos de graduação de um curso de inglês instrumental na Faculdade de Letras (UFMG). O impulso motivador foi a tentativa de criação de um meio para resolver um problema educativo localizado: o aumento do nível de compreensão de textos em inglês para
\end{abstract}

* reinildes@gmail.com 
fins acadêmicos. O processo de busca de uma possível solução envolveu o uso de mapas conceituais (NOVAK; CANAS, 2008), mediados pelo programa de computador CMap Tools (CAÑAS et al., 2004). Os dados indicam que a criação de mapas conceituais, empoderada pelo uso do CMap Tools, pode ser uma estratégia útil para aumentar o nível de compreensão escrita dos alunos. A investigação teve como suporte teórico os princípios da abordagem de inglês para fins específicos, aprendizagem significativa, aprendizagem como um ato social e aprendizagem colaborativa.

PALAVRAS-CHAVE: mapas conceituais, programa de computador CMap tools, compreensão escrita para fins específicos em inglês.

Applied linguistics may be primarily concerned with solving educational problems related to the acquisition and learning of an L2. It may engage, for instance, in the development of practical classroom research using theory and methodological approaches from different fields of study. The results obtained can then provide a solid foundation for the creation of teaching materials for pedagogical applications. The action-research (STRINGER, 2007) described in this paper aimed at providing an optimal solution to an educational problem, namely, the enhancement of students' reading comprehension in English with the use of concept maps powered by a computer software, the CMap Tools (<http://cmap.ihmc.us/download/>). Participants were enrolled in an ESP course to develop comprehension of texts related to their specific fields of study. They were also encouraged to use reading strategies for better comprehension and became aware of the fact that reading is an active process which requires their involvement in constructing meaning from texts. Concept maps were understood as a means of visually illustrating major concepts and the relationships or links between them.

In this article, I intend to discuss the procedures of this action-research, which was conducted with a group of Brazilian undergraduates. First, I will briefly discuss the main features of the ESP approach and then I will focus on reading as an active process. The notions about concept maps and the characteristics of the CMap Tools software will also be addressed. The design of the research project will then be discussed, followed by a description of the context, including the subjects who participated in the study. Finally, I will discuss the results obtained. I can say from the outset that the use of concept maps to represent textual relationships proved to be effective for the enhancement of text comprehension in English. Results provided both understanding and evidence of change in students' reading strategies. 


\section{English for specific purposes (ESP)}

Traditionally known as "inglês instrumental" in the Brazilian context, the ESP approach focuses on students' needs concerning the use of English for academic and career purposes (whether related to oral or written skills). The underlying belief is that students' abilities in their subject-matter fields improve their ability to acquire English. An ESP program may thus enhance reading skills for those who need to read academic papers and books as part of their university course requirements and job functions. Similarly, it may promote the development of oral skills in a class of students who are studying English to become tour/travel guides, taxi drivers or hotel receptionists, for example.

This concern with students' needs reflects the learner-centered philosophy adopted by the ESP approach from its inception, following the shift from viewing learning as a passive activity to a dynamic process where learners are active participants in the learning process (AUSUBEL, 1968; LEAHEY; HARRIS, 1985; NOVAK; GOWIN, 1984; NOVAK, 2010). When ESP was first developed, educational principles began to depart from the behavioral belief in habit formation to emphasize the important role thinking processes play in language learning. This resulted in full acknowledgement of the importance of learners' previous knowledge and previously developed cognitive abilities. There was also agreement around the existence of "mental processes underlying responses, concept formation and the nature of human comprehension" (MONTANER, 1982). These notions hold true throughout the years.

It was believed (and still is) that learners are in control of their learning and make use of strategies to learn according to their needs. Good language learners are risk-takers, since they have to reason, face challenges and make errors in order to succeed. In order to put learners in control of their learning, reading strategies started being taught in the context of ESP for reading, particularly in Brazil. These strategies included: the use of previous knowledge, context, cognates, nonverbal information, spatial organization of text layouts, and textual characteristics of genres.

Recently, the ESP approach for the development of reading skills, particularly in the Brazilian context, started to incorporate Vygotskyan ideas about learning into materials and teaching methods. As a result, the approach takes into consideration the relevance of interactions between pairs of students who work in collaboration to be more successful learners. Therefore, learning is also viewed from a social perspective, where social encounters impact 
meaning and understanding (VYGOTSKY, 1962). Furthermore, digital technologies have also been integrated into courses and materials for learning purposes according to students' needs.

The ESP approach has adopted the notion of language as a means of communication based on the influential ideas taken from studies in linguistics in the late 70s and early 80s (CANDLIN, 1979; HYMES, 1981; WIDDOWSON, 1978; LEAHEY; HARRIS, 1985). As stated by Widdowson (1978), for instance, we use language to achieve specific communicative purposes - "we are not just walking grammars" (p.2). From his viewpoint, "language usage" refers simply to "the citation of words and sentences as manifestations of the language system", while "language use" is "the way the system is realized for normal communicative purposes" (p.18). These views reflect the shift of focus away from formal structures at the sentence level toward discourse as a whole and to the ways language is used in real communicative situations. In teaching, the aim turns to the development of learners' "ability to understand the functioning of language in use" (ALLEN; WIDDOWSON, 1981, p. 124). As such, ESP concentrates more on language in context than on teaching grammar and language structures. Its focal point is that English is not taught as a subject separate from the students' real world, but rather integrated into a subject-matter that is important to the learners. Given the relevance of discourse as a whole, ESP classes use authentic texts taken from real sources and, as result, the textual aspects and how ideas are interconnected in a text become of paramount importance.

\section{Reading in ESP classes}

Reading as an active process has been one of the major underlying principles in the ESP approach since its emergence. The break away from the idea that readers are passive recipients of information can be considered as one of the most important contributions this teaching approach has made to the understanding of how readers comprehend a text. As Leahey and Harris (1985) stated, "a fundamental assumption is that ... [a] written text [does] not in itself carry meaning; rather, it provides directions for ... readers on how to use their own stored knowledge to retrieve and construct the meaning" (p. 201). As such, reading is an interactive process during which readers make use of two types of movement: top-down (from their previous knowledge) and bottomup (from the text itself, based on the clues provided by the author and on the way the information is internally organized). Previous knowledge is more than 
just world knowledge. It may also refer to cultural and social values which influence comprehension, information about textual structures in different genres already socially constructed in the L1 context, and lexical-grammar knowledge woven into the text. The use of the two moves (top-down and bottom-up) demonstrates that reading is an interactive process between readers, texts and context. What readers bring to the text, their prior knowledge, is as important as what they gain from it. The meaning does not lie in the text itself, but rather it is shaped, "reshaped and reinterpreted by readers in different contexts of use and different purposes" (WALLACE, 2005, p.15).

From its beginning, in order to meet students' reading needs, the ESP approach has emphasized the development of print literacy and has used authentic texts mostly taken from the academic domain, such as abstracts, chapters of books, articles, diagrams, tables and maps. Teaching materials have also incorporated the view of reading as a social activity; "social in the sense that readers and writers enact their roles as members of communities; social in that it unfolds in a social context, both an immediate and wider social context" (WALLACE, 2005, p.9). Texts are then viewed as social constructs, following Bakhtin's (1986) belief that texts realized as genres are socially and culturally recognizable language events as, for example, research reports, dissertations and book reviews (not to be confused with rhetorical categories, such as descriptions, expositions and narratives). The genre-based perspective has already been a long-time tradition in the ESP approach.

Throughout the years, the development of visual literacy has been systematically emphasized in ESP classes where nonverbal devices, such as pictures, graphs, maps, tables, line drawings and diagrams, have been explored as features of written discourse in reading comprehension (DIAS, 1985). Furthermore, as page layouts (modes of spatial compositions) are different for the various genres that are socially recognized, they have also been part of the interpretation process. The underlying belief is that meaning arises from the integration of both semiotic codes: verbal and nonverbal. More recently with the advent of the Internet, it has been acknowledged that reading comprehension depends on the interpretation of multimodal texts that combine different semiotic codes (KRESS; van LEEUWEN, 2006). This concept has also been integrated into recent teaching materials for ESP classes. 


\section{Concept maps}

This strategy for reading comprehension has been extensively investigated in a variety of contexts, which include reading comprehension for recall of information, writing skills, science education, and testing. It has been studied with different age groups ranging from elementary to graduate students, mostly in the L1 context; however, some research has also been conducted related to the enhancement of reading comprehension in L2 (DIAS, 1998; ROSENBERG; SAIF, 2010). Previous research has revealed that one of the difficulties in implementing concept mapping as a reading comprehension strategy is the difficulty in convincing learners to make use of a learning tool with which they are not familiar (NAIDU, 1991). Another apparent challenge is that map-drawing is a time-consuming task that involves considerable effort on the part of the "mappers", which may discourage learners from integrating this practice into their routine study habits (NAIDU, 1991). However, the present study indicates that students can become interested in text-mapping once they become aware of its usefulness to enhance text comprehension in English and when they become skillful in the use of the CMap Tools software for the creation of their maps.

A key element in mapping information from a text involves creating linkages between two or more concepts using "linking words or phrases to form a meaningful statement" (CAÑAS; NOVAK, 2008). Various statements can be read from a concept map about any major concept that has been mapped - it displays a visual representation of what has been understood by the "mapper", thus fostering meaningful learning (AUSUBEL, 1968; NOVAK, 2010). The key notions about concept maps are shown in FIG. 1 (CAÑAS; NOVAK, 2008) and statements created in a progression from the top downward the figure will reveal their major characteristics. As examples of such statements, the following can be mentioned: "Concept maps represent organized knowledge necessary for effective teaching as well as for effective learning"; "Concept maps help to answer focus question(s) which are context dependent"; or even "Concept maps represent organized knowledge that is comprised of concepts connected by linking words to form propositions". 


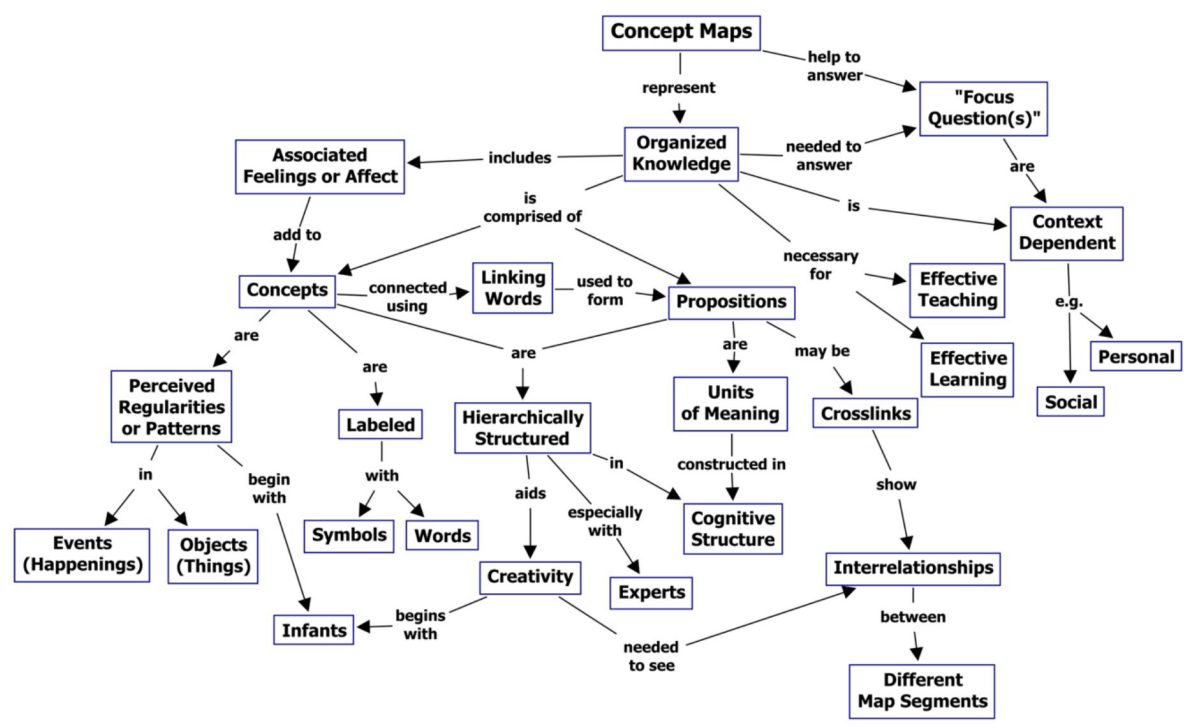

FIGURE 1 - A concept map showing the key features of concept maps

(CAÑAS; NOVAK, 2008)

The process of concept mapping can also be understood from a Vygotskian perspective, in that learning is a social process in which interactions among peers play an essential role. It may be added that the task of concept mapping also includes scaffolding (WOOD; BRUNER; ROSS; 1976) and collaboration. Scaffolding means assistance to the learner provided by different means, such as language and technological tools. In the task of concept mapping, students are scaffolded by the interactions with peers as well as through the use of the CMap Tools software, ultimately enhancing learning. Both types of assistance will focus on experience during the process of reading, thinking, linking ideas, creating propositions and constructing text comprehension. It is important to note that effective scaffolding makes it easier for the learner to successfully complete a task. Collaboration among peers may thus include the following benefits: active involvement of students in the learning process, development of students critical thinking skills, creation of learning communities and use of them to collaborate and learn, increase of students' self-esteem; reduction of students' levels of anxiety (cf.: LAMY; HAMPEL, 2007, p. 65-66) 


\section{The IHMC CMap Tools software}

The IHMC CMap Tools is a free software suite that has been developed at the Institute for Human and Machine Cognition (IHMC) in the United States (CAÑAS, A.J.; HILL, G.; GARFF, R.; SURI, N.; LOTT, J. ESKRIDGE, T. 2004, "http://cmap.ihmc.us" http://cmap.ihmc.us). It can facilitate "the collaborative construction, sharing and publishing of knowledge models represented as concept maps." It empowers learners to create propositions connected by specific linkage words to more effectively portray textual relationships. This software makes it easy for users to construct and modify concept maps during the mapping process, while allowing them to collaborate at a distance via the Internet. Users can also publish their maps in the virtual space so that anyone connected to the web can access them. It allows for "both synchronous and asynchronous collaboration during the construction of concept maps" in a World Wide Web (WWW) environment that can foster collaboration and the possibility of representing and sharing knowledge among mapmakers and users all over the world. As stated by Novak and Cañas (2004), this computer software can provide extensive support "for the collaborative construction of concept maps by groups, whether they are at the same location or in distant locations", and this can ultimately facilitate learning and retention of information. Furthermore, devices from different semiotic codes, such as visual and audio, can be inserted into a concept map, turning it into a multimodal environment for learning. Different types of documents and WWW links can also be attached to maps. The CMap Tools software can be downloaded for free at " $<$ http://cmap.ihmc.us/download/>" <http:/ /cmap.ihmc.us/download/>. Numerous examples of concept maps that have been created with the use of this software can be found at " $<$ http://www.cmappers.net/>" $<$ http://www.cmappers.net/>.

\section{Design of the action research}

Action research is "a systematic approach to investigation that enables [teachers] to find effective solutions to problems they confront in their [daily practices]" (STRINGER, 2007, p.1). Typically, this type of research is undertaken to assist teachers to deal with the complexity of the issues they face in their classrooms, so as to make their work more meaningful and rewarding. "Unlike traditional experimental/scientific research that looks for general explanations that can be applied to all contexts, action research focuses on specific situations and localized solutions" (STRINGER, 2007, p.1), allowing teachers to address their most important concerns, such as investigating ways to improve learning and 
increase student achievement. It is thus a way to reflect on issues that impact classroom practices - it is context bound and addresses real-life problems. Collaboration is paramount since participants are co-researchers and the ideas shared are equally significant. Furthermore, in an action-research project, theory informs practice and practice refines theory in a continuous process of transformation. The techniques for gathering data can include: interviews, written reports, checklists, individual files of students' work and / or opinions, portfolios and questionnaires. "To enable teachers to become continuous learners, to create new forms of professional development, to develop research questions based on teachers' own curiosity about teaching and learning in their classrooms" are some of the reasons why we engage in action-research projects (BURCH, 2004).

This action-research project was undertaken to solve a real educational problem, that is, the enhancement of Brazilian undergraduates' reading comprehension of texts written in English. The phases of the research process are outlined in TAB. 1.

\section{TABLE 1}

Phases of the action-research project

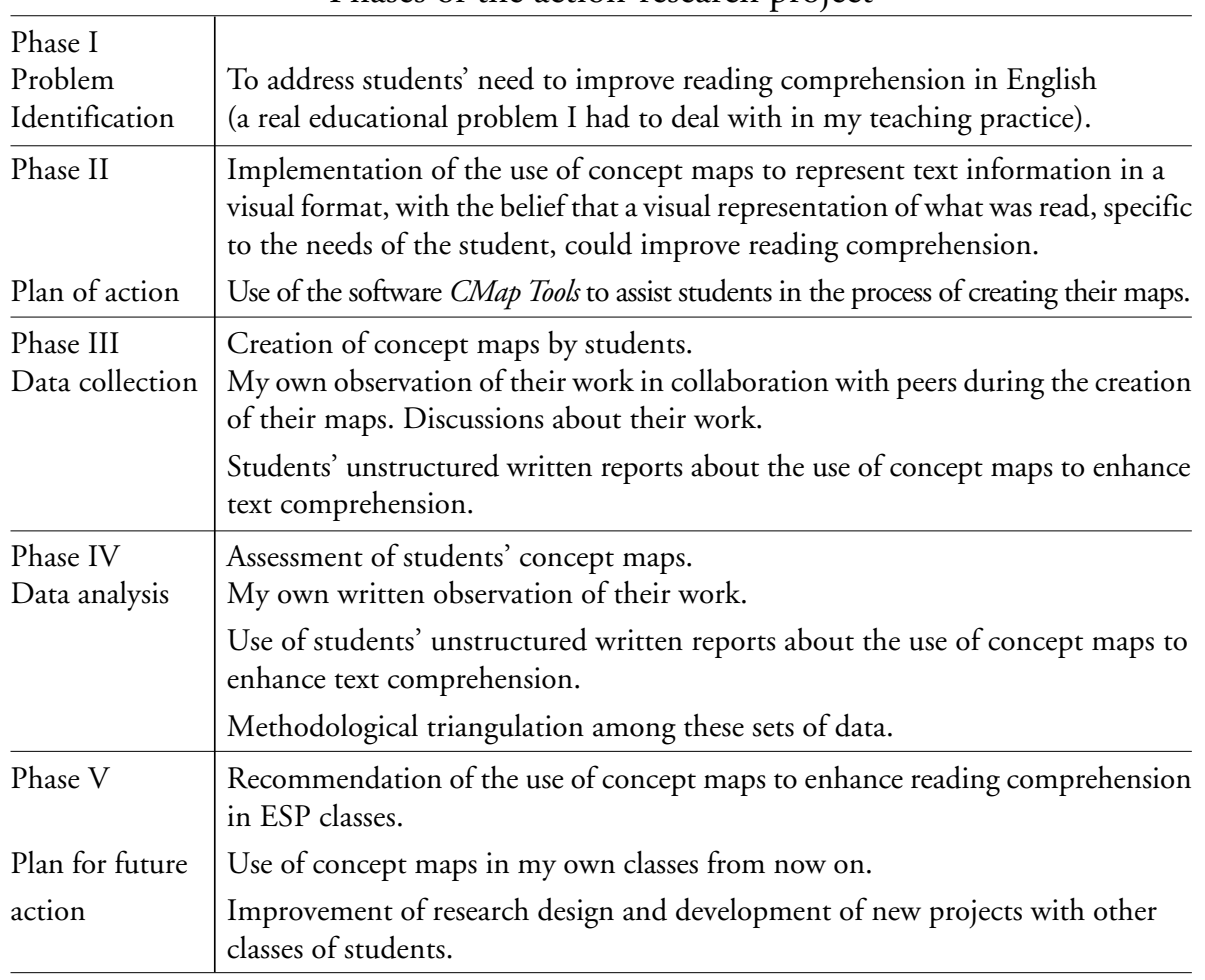


The research setting was a classroom at Faculdade de Letras (UFMG) in Belo Horizonte. The subjects were eight students from different fields of study (engineering, social studies and language) who were taking the course "ESP for reading" and the researcher was myself as the teacher of the group. These students could be classified as "false beginners", that is, they had previously developed some grammar and vocabulary competence, but had difficulty with longer written texts, including those related to their own fields of study.

I decided to make them aware of the importance of representing the concepts and notions of a text and their inter-relationships through a visual format. My primary objective was to help them understand that, while creating a visual representation of the texts they had read, they could more effectively relate the arguments and ideas discussed in the text. I decided to use the CMap Tools software (<http://cmap.ihmc.us/download/>) as the means for creating visual representations of what they had read. The students downloaded the software onto the lab computers and at home. They took the tutorial provided at <http://cmap.ihmc.us/Support/Help/> and collaborated with each other during the process through online forums, e-mails and in person when attending my class. This tutorial consists of various sections including: using CMap Tools (video), create a Cmap, add a concept, create propositions (video), etc. By taking the tutorial, students acquired knowledge and developed skills concerning the CMap Tools software while using it with the texts they had to read for the other disciplines of their curriculum. In terms of the task of map creation, students were recommended to follow Dias's (1998) expanded guidelines about how to build a concept map. They are shown in TAB. 2 . 
TABLE 2

Guidelines for creating concept maps

In a word document:

List the key concepts in the L2 text. Beside them, list the related concepts that have been found. (If a class is working with the same text, groups exchange their lists for feedback from each other).

Go back to the text. Enlarge your list if necessary.

Draw a matrix to show the relationships between concepts. List all the concepts you identified down one side and repeat them across the top. Relationships between concepts are shown in the boxes where a row and a column intersect. The resulting matrix of relationships will provide a useful checklist for the creation of a concept map for each text you read. Also list the linking words that can be used to set up the relationships.

Open a new page on CMap Tools. Organize the hierarchical structure. Discuss it with your teacher and peers. Send the first version to them and to me. Get feedback from us.

Reread the text. Check if you missed important information. Go on creating your map. Repeat this cycle. Reread the text. Check the concepts and the setting up of relationships. Ask this question: Is my concept map a picture of my comprehension of the text? Add and/or delete information. Make a nice layout.

Write some propositions based on your concept maps. Do they make sense? Check them with a peer or with your teacher.

Create the final version. Share it with the world (by using Cmap Sharing Tools) if you want to.

Data were collected from three sources: 1 . the concept maps created by the students in individual files sent to me; 2. my own observation notes of what they did in collaboration with peers during the creation of their maps, in addition to their participation in class debates; and 3. their unstructured written reports about the use of concept maps to enhance text comprehension. They were encouraged to write about their feelings and their sense of accomplishment related to the task of concept mapping to enhance reading comprehension in English.

\section{Data Analysis}

My assessment of the use of concept maps is that the students not only learned how to create the maps by using the CMap Tools software, but also enhanced their comprehension of texts in English due to the new representations that were visually displayed in the concept maps. There was also an increase in the quality of the maps created by the students throughout the semester in my viewpoint this was an indication that they were reading texts more thoroughly. As concept maps are pictures of the understanding of something, 
I could see how much the students comprehended the texts they had mapped. It should also be noted that the entire group of students in the ESP class participated in the task of map creation and demonstrated that they really enjoyed creating them. It can be stated that they had grasped the usefulness of this task for better reading comprehension.

My assessment of the quality of the maps (that is, how much they reflected an understanding of what was read) was based on the following set of parameters: 1. Identification of the main concept: Were there distinctions between the main and subordinate concepts?; 2. Propositional links: Were the concepts joined by adequate linking words? Did the linkages represent students' pictures of what they had read?; 3 . The hierarchical organization of the text in a visual format: Did the concept map clearly display the main and subordinate concepts?; Did the concept map reflect a skillful use of the CMap Tools software?

My own notes taken throughout the course based on my observations of students' participation during classroom debates on the process of creating their own maps also helped me in the assessment of their reading comprehension.

With respect to the participants' unstructured written reports, these revealed that students were using the strategy to study for the other subjects on their course load. They also remarked that they would continue using it. Their own reports also revealed the positive impact the process of map drawing had on their awareness of the reading process, as well as how they achieved greater control over reading comprehension in English by visually representing what was conveyed in the texts they had read. One student said,

Now I can better understand how the arguments of a text are structured in terms of definitions, exemplifications, discussions in favor or against a specific view point. By mapping a text, I follow the arguments more easily and, as such, I understand them more deeply, which helps me in later recall ... for instance, when I have to use what I learned from texts I mapped in a class presentation or in a paper I have to write about the subject. (my translation)

In fact, what I noticed throughout the semester was that mapping a text, or rather, creating a visual representation of it, can enable students to follow how authors organize and bring together their arguments around a specific topic in the texts they write. These texts may take the form of different genres, namely, academic articles, reports, interviews, critical reviews, and so forth. For 
example, a concept map of the online scientific article Alternative fuel vehicle, ${ }^{1}$ mapped by one of my students, graphically showed the world's need for this type of vehicle; the argumentative support for this urgent necessity; what an alternative fuel vehicle is; how it can be developed; its effects on the environment; what has been done thus far for its development; examples of agencies and governments that have been involved in the quest for this type of vehicle; etc. (FIG. 2).

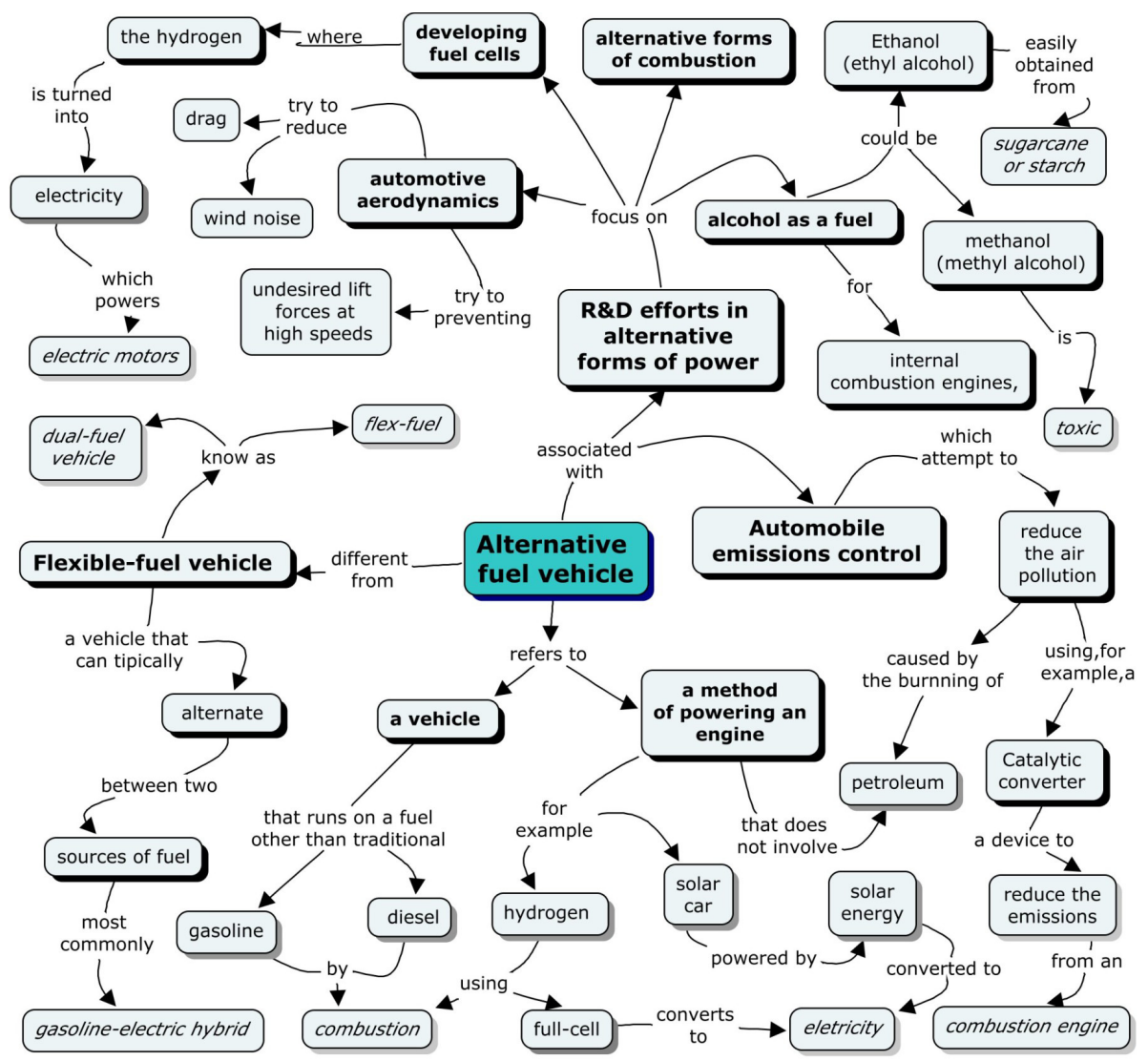

FIGURE 2 - A concept map of the key features of an alternative fuel vehicle

As the mapped graph is a visual representation of the textual format, it can be more easily understood, and what is learned from it can be retained and

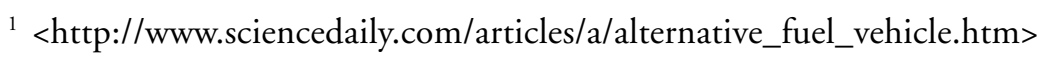


recalled more easily too. Furthermore, if the maps are created with the software CMap Tools, links can be attached to the map and this will add further information - even from different types of media - that can be accessed (and/ or reviewed, rewritten, added, deleted) at any time. Another additional advantage is that the map can be shared with others, which facilitates collaboration, leading to improved quality of the material that has been graphically displayed. Debates can be held about the information they display both synchronously or asynchronously.

With respect to collaborative learning, I noticed that students got more actively involved in the learning process, increased their self-esteem and experienced reduced levels of anxiety. In addition, I observed that critical thinking skills were developed while the students kept involved in a continuous process of interaction through our online learning communities. This also fostered a diverse understanding of what had been read for comprehension and, as a result, we had heated debates in the classroom. Students were aware of the fact that I was gathering data about our work throughout the semester and all agreed to participate in the action-research project.

Triangulation refers to the use of more than one approach to data analysis in order to enhance confidence in the subsequent findings. Although this research project did not attempt to apply general explanations to all contexts, but rather focused on a localized solution to an educational problem, the results were analyzed using different means. These included: my own observations recorded through notes taken during our interactions, my assessment of students' concept maps based on a set of previously established criteria, and the students' own written reports about the experience we shared together. The data collected from each source seem to support the notion that map creation is a useful strategy to enhance reading comprehension in English. However, additional studies are required in the context of ESP classes in order to obtain greater confidence in the results, as well as a more widespread recommendation of concept maps as a strategy to develop students' reading competence.

\section{Concluding remarks}

Based on the action research reported in this paper, it can be stated that the creation of concept maps with the CMap Tools software can empower ESP students in different ways. First, they will learn to organize and structure knowledge acquired from texts in another semiotic code: the visual one. 
Second, through the representation of texts graphically shown on the computer screen and the relationships between concepts being more evident, students' comprehension and retention of text frameworks will be enhanced. Third, students will also become aware of the fact that they can read well in English for their academic / career needs, once they apply appropriate strategies. Furthermore, their self-esteem will increase as they feel they are able to comprehend texts written in English in a more efficient way.

There are various advantages to using the Cmap Tools software to empower students. In addition to facilitating the process of collaboration while students are involved in the task of concept mapping their texts, it will also guarantee access of different Internet users to the maps that can be virtually published, and online debates can be held at any time. Maps can also be modified and subordinate concepts and examples can be added based on ideas shared online. The virtual storage of maps may last forever and mappers can go back to their work many years after they have been created for further reflection, changes and sharing of ideas with others. Therefore, students will become more effective learners and knowledge creators, able to fluently read texts from their fields of study. As mentioned in the foreword to Novak's (2010) latest publication, "The central purpose of education is to empower learners to take charge of their own meaning making." The use of concept maps powered by the CMap Tools software can be a useful and efficient strategy to achieve this goal in ESP classes.

\section{References}

ALLEN, J. P. B.; WIDDOWSON, H. G. Teaching the commucative use of English. In: BRUMFIT, C. J.; JOHNSON, K. (Ed). The communicative approach to language teaching. 2. ed. Oxford: Oxford University Press, 1981, p. 122-142. AUSUBEL, D. Educational psychology: a cognitive view. New York: Holt, Rinehart \& Winston, 1968.

BAKHTIN, M. Speech genres and other late essays. Austin: University of Texas Press, 1986.

BURCH, C. Classroom action research. 2004. from: <http://oldweb.madison. k12.wi.us/sod/car/carhomepage.html>. Retrieved in: February, 10, 2011.

CAÑAS, A. J., HILL, G., CARFF, R., SURI, N., LOTT, J., ESKRIDGEE, T. (2004). CmapTools: A knowledge modeling and sharing environment. In: CANÃS, A. J.; NOVAK, J. D.; GONZÁLEZ, F. M. (Ed.). Concept maps: theory, methodology, technology. Proceedings - 32 -of the first international conference on concept mapping (v. I, p. 125-133). Pamplona, Spain: Universidad Pública de Navarra. 
CANDLIN, C. Preface. In: MACKAY, R.; MOUNTFORD, A. (Ed). English for specific purposes. 2. ed. London: Longman, 1979.

COPE, B.; KALANTZIS, M. (Ed.). Multiliteracies: literaccy learning and the design of social futures. London: Routledge, 2000.

DIAS, R. The semiotics of written discourse and the dual representation of information in memory: an application of nonverbal elements to FL reading methodology. 1985. Dissertação (Mestrado em Inglês) - Faculdade de Letras da UFMG, 1985. DIAS, R. Effects of combining system-assigned strategies with learner-based activities in reading in English as a foreign language. 1998. Tese. (Ph.D em Tecnologia Educacional) - Concordia University, Montreal, QC, 1998.

HYMES, D. H. On communicative competence. In: BRUMFIT, C. J.; JOHNSON, K. (Ed). The communicative approach to language teaching. 2. ed. Oxford: Oxford University Press, 1981, p. 5-24.

KRESS, G.; van LEEUWEN, T. Reading images: the grammar of visual design. 2. ed. New York: Routledge, 2006.

LAMY, M.N.; HAMPEL, R. Online communication in language learning and teaching. New York: Palgrave Macmillan, 2007.

LEAHEY, T; HARRIS, R. Human learning. 2. ed. Englewood Cliffs, NJ: Prentice-Hall, 1985.

MONTANER, A. H. B. Reading for academic purposes. 1982. Dissertação. (Mestrado em Linguística Aplicada e Estudos da Linguagem) - Pontifícia Universidade Católica de São Paulo, São Paulo, 1982.

NAIDU, S. Effects of post-questioning, concept mapping and feedback on cognitive performance in distance education. Tese. (Ph.D em Tecnologia Educacional) Concordia University, Montreal, QC, 1991.

NOVAK, J. D.; CAÑAS, A. J. The theory underlying concept maps and how to construct them. Technical Report IHMC CmapTools 2006-01 Rev 01-2008, Florida Institute for Human and Machine Cognition, 2008. from: <http:// cmap.ihmc.us/Publications/ResearchPapers/TheoryUnderlyingConcept Maps.pdf>. Retrieved in: February 13, 2011.

NOVAK, J. D.; GOWIN, D. B. Learning How to Learn. New York: Cambridge University Press, 1984.

NOVAK, J. D. Learning, Creating, and Using Knowledge: concept maps as facilitative tools in schools and corporations. 2. ed. New York: Routledge, 2010. ROSENBERG, R.; SAIF, S. Computer-based concept mapping for second language reading comprehension: A design-based research study. In: SÁNCHEZ, J.; CAÑAS, A.; NOVAK, J.D. (Ed). Concept Maps: Making 
Learning Meaningful. Proceedings of Fourth Int. Conference on Concept Mapping. Viña del Mar, Chile, 2010, p. 24-28.

STRINGER, E. T. Action Research. 3. ed. Thousand Oaks, CA: Sage publications, 2007.

VYGOTSKY, L. Thinking and speaking. Massachusetts: MIT Press, 1962.

WALLACE, C. Critical reading in language education. New York: PalgraveMacmillan, 2005.

WIDDOWSON, H. G. Teaching language as communication. 4 ed. Oxford: Oxford University Press, 1978.

WOOD, D. J.; BRUNER, J. S.; ROSS, G. (1976). The role of tutoring in problem solving. Journal of Child Psychiatry and Psychology, 17(2), 89-100.

$<$ http://www.sciencedaily.com/articles/a/alternative_fuel_vehicle.htm>. Retrieved in: February 20, 2011.

Recebido em 27/2/2011. Aprovado em 12/4/2011. 